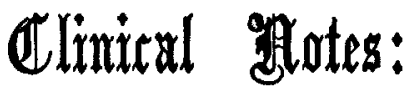 \\ MEDICAL, SURGICAL, OBSTETRICAL, AND THERAPEUTICAL.}

\section{NOTE ON A CASE OF SIMULTANEOUS RUPTURE OF A CAROTID ANEURYSM AND AN ATHERO. MATOUS AORTA.}

By F. L. Sandiland, M.R.C.S. ENG., L.R.C.P. Lond, ASSIBTANT MEDICAL OFFICER TO THF BETHNALL HOUSE ASYLUM, CAMBRIDGE ROAD, N.E.

THE patient, a woman, aged 77 years, was admitted to the Bethnall House A sylum in August, 1905. She was suffering from alcoholic dementia. When examined on admission her heart was found to be normal except for some accentuation of the aortic second sound. She had no physical signs of aneurysm, but the arteries were hard and thickened. The case was considered to be one of arterio-sclerosis, with chronic interstitial nephritis. During the year the patient had several attacks of syncope in which she became unconscious for varying periods. On O.t. 15th, 1906, at dinner, she was eating a piece of bread when her hands fell to her sides and she became unconscious. On the immediate arrival of the medical officer she was found to be dead. Death was surmised to be due to a fatal attack of syncope.

Necropsy.-On opening the pericardium some blood and serum were found to be present. The right ventricle was flabby and relaxed, while the left was firmly contracted. Neither of the ventricles contained any blood. The membrana ovale on the septam auriculi was bulged in towards the right auricular cavity like the finger of a glove. The aortic valves were thickened at their attached margins and there was some atheroma round the roots of the coronary arteries. The arch of the aorta showed some general dilatation, but there was no definite aneurysm. Oo opening the aor!a throughout its length more atheromatous patches were found. One of these situated below the roots of the great vessels on the posterior wall had given way. The rupture was $V$-shaped and marked out the limits of the patch, one limb extending down to just within the limits of the pericardium. Hæmorrhage had taken place into the tissues in front of the bifurcation of the trachea. On removing the brain extensive hæmorrhage was found spreading all over the base beneath the arashnoid membrane. The blood clot being washed out from the cisterna basalis, the exposed arteries at the base were found to be degenerated extensively. An aneurysm of the left internal carotid was present between its entry through the skull and its division into the anterior and middle cerebrals. This aneurysm was three-quarters of an inch in diameter and fusiform in shape. It had ruptured on its outer aspect, causing the basal bæmorrhage. The rupture was three-eighths of an inch long. The atheroma of the arteries extended along their branches deep into the cerebrum. As regards the other crgans, the kidneys showed advanced cirrhosis; the liver was large, greasy, and tough ; and the spleen was tough and fibrous.

This case seems to be of great rarity on account of the simultaneous rupture of both the aorta and the carotid. Had one ruptured first the lowering of the blood pressure should, according to physiological teaching, have precluded the rupture of the other. The conclusion is that both occurred simultaneously.

Cambridge-road, N.E.

\section{A CONVENIENT TEST FOR THE PRESENCE OF BINOCULAR TISION.}

By A. Freeland Fergus, M.D. Glasg.

For the testing of the presence or absence of binocular vision there are already ample means. In addition to Hering's apparatus we have the useful instrument designed by Claud Worth which for the investigation of this important function leaves little to be desired. The pictures devised by him which seem to me to be the best for the purpose are the circles. One can at once tell whether any patient has the sense of binocular vision by simply getting his answer to the question of whether the outer or the inner circle appears to be the nearar. By changing the position of the circles the surgeon can at pleasure cause the outer or the inner to appear the nearer to a person gifted with fully developed

binocular vision, and thus if invariably a patient answers correctly there is then no doubt as to his perception of the third dimension. The only objection to Worth's instrument is that it would cost a great deal to have a sufficiency of instruments to meet the requirements of a clinique where a very large number of squint patients are in attendance. Moreover, there are obvious difficulties in the way of a patient using such an apparatus in his own house.

Stereoscopic exercises must in many cases be carried on for a prolonged period if the best results are to be obtained after operations for squint. Most of the stereoscopes in ordinary use are, to my mind, unsatisfactory. Take, for example, Doyne's elaborate instrument or the more simple one of Lindolt, both of which at one period I used extensively. With these we can test whether a patient can see with both eyes at the same time, for if he does he sees both the upper and the lower half of the figure, and by a little adjustment he can arrange the two halves to make one figure. But it is to be observed that the two halves appear at the same distance from the observer and therefore neither of these instruments gives any information as to whether the person being examined has the consciousness of the third dimension of space. These instruments have, however, certain uses ; for example, they can be employed to train the convergence, positive and negative, but they do not serve for testing the sense of perspective. One of the most convenient methods of investigating this is afforded by those ingenious pictures which are called plastograms. These may be said roughly to consist of two superposed pictures of the same subject taken from slightly different points of view. One of the pictures is printed in green and the other in red and they are looked at through glasses similar to those employed by Professor Snellen for the detection of simulated blindness of one eye. If binocular vision with the perception of the third dimension be present, so soon as the spectacles are worn a stereoscopic $\epsilon$ ffect is obtained at once.

How can we ascertain that the patient has the consciousness of the third dimension? It avails nothing to ask him if certain objects appear nearer than others. Just as a man examining a picture knows that some objects are nearer than others, so the parson examining the plastograms can easily tell without having the perception of the third dimension that some objects in it are meant to appear closer to him than others. For example, he knows that a statue must be nearer to him than the building behind it. All doubt on the matter can easily be dispelled by asking the patient to sway himself slowly from side to side while examining the plastograms. Anyone who does so and who has fully developed binocular vision will find that the objects in the foreground appear to move in the same direction as he moves. If he shuts one eye this apparent movement at once ceases; the condition of its being present is that both eyes are used simultaneously. It is to be observed that some of the pictures are much better adapted for the purpose than others, and before usiug any particular picture the surgeon should satisfy bimself of its suitability.

Glasgow.

\section{A}

OF

\section{HOSPITAL PRACTICE BRITISH AND FOREIGN.}

N lla autem est alia pro certo noscendi via, nisi quamplurixas et mocborum et dissectionum historias, tum aliorum tum propris c llectas habere, et inter se comparare.-MoRGAGNI De Sed. et Cous. Mory., lib. iv., Procmium.

\section{LONDON HOSPITAL}

A CASE OF U MSAREAN SECTION FOLLOWED BY THE REMOYAL OF A FIBROID TUMOUR WHICH FILLED THE PELVIC CAVITY.

(Under the care of Dr. H. R. ANDREws.)

A WONAN, aged 33 years, was seen in consultation on March 7th, 1906. She had bad pelvic discomfort and increasing difficulty in passing urine for several days, culminating in complete retention on March 5th, when tro and a half pints of urine were drawn off by catheter. After the bladder had been emptied she had had frequency of 